\title{
"Impact of organizational politics on proactive behavior of government employees: the moderating role of self-efficacy"
}

\begin{tabular}{|c|c|}
\hline \multirow{3}{*}{ AUTHORS } & Fauzan Ali Rasvid in httns:/orcid oro \\
\hline & M Sandi Marta iD https://orcid.org/0000-0002-5348-3267 \\
\hline & R http://www.researcherid.com/rid/AAA-9773-2020 \\
\hline ARTICLE INFO & $\begin{array}{l}\text { Fauzan Ali Rasyid and M Sandi Marta (2020). Impact of organizational politics on } \\
\text { proactive behavior of government employees: the moderating role of self-efficacy. } \\
\text { Problems and Perspectives in Management, 18(1), 385-393. } \\
\text { doi:10.21511/ppm.18(1).2020.33 }\end{array}$ \\
\hline DOI & http://dx.doi.org/10.21511/ppm.18(1).2020.33 \\
\hline RELEASED ON & Friday, 03 April 2020 \\
\hline RECEIVED ON & Wednesday, 18 December 2019 \\
\hline \multirow[t]{2}{*}{ ACCEPTED ON } & Friday, 27 March 2020 \\
\hline & $((\mathrm{cc}) \mathrm{EY}$ \\
\hline LICENSE & $\begin{array}{l}\text { This work is licensed under a Creative Commons Attribution } 4.0 \text { International } \\
\text { License }\end{array}$ \\
\hline JOURNAL & "Problems and Perspectives in Management" \\
\hline ISSN PRINT & $1727-7051$ \\
\hline ISSN ONLINE & $1810-5467$ \\
\hline PUBLISHER & LLC "Consulting Publishing Company "Business Perspectives" \\
\hline FOUNDER & LLC "Consulting Publishing Company "Business Perspectives" \\
\hline
\end{tabular}

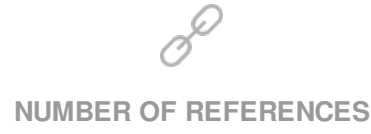

33

\section{NUMBER OF FIGURES}

1
ニ:-

NUMBER OF TABLES

2

(c) The author(s) 2021. This publication is an open access article. 


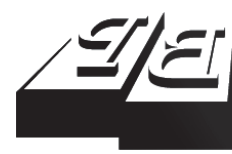

BUSINESS PERSPECTIVES

(O)

LLC "CPC "Business Perspectives" Hryhorii Skovoroda lane, 10, Sumy, 40022, Ukraine www.businessperspectives.org

Received on: $18^{\text {th }}$ of December, 2019 Accepted on: $27^{\text {th }}$ of March, 2020 Published on: $3^{\text {rd }}$ of April, 2020 (c) Fauzan Ali Rasyid,

M Sandi Marta, 2020

Fauzan Ali Rasyid, Dr. (Political Science), Dean, Faculty of Sharia and Law, Department of Politics, State Islamic University Of Sunan Gunung Djati Bandung, Indonesia.

M Sandi Marta, M.S., Lecturer, Faculty of Economic and Islamic Business, Department of Management, State Islamic University of Sunan Gunung Djati Bandung, Indonesia. (Corresponding author)

\section{IMPACT OF ORGANIZATIONAL POLITICS ON PROACTIVE BEHAVIOR OF GOVERNMENT EMPLOYEES: THE MODERATING ROLE OF SELF-EFFICACY}

\begin{abstract}
In today's organizational environment, human resources are seen to be one of the most crucial assets that must be maintained, particularly the existence of employees' proactive behavior, which is needed for the sustainability of organizational performance. One factor, which may affect the employees' proactive behavior, is organizational politics. Therefore, the main objective of this study is to investigate the effect of organizational politics on proactive behavior of government employees and to test further whether this effect was moderated by self-efficacy. This study used a quantitative approach with an exploratory method to answer the proposed hypothesis. The samples were 310 local government employees in Bandung district, Cimahi City, Bandung City, and West Bandung Regency, Indonesia. For processing the data and testing the hypotheses, this research employed Moderated Regression Analysis by using STATA 13. The results showed that organizational politics has a negative effect on the proactive behavior of government employees, and the moderation effect of self-efficacy can weaken the negative relationship between organizational politics and proactive behavior. The study, therefore, makes a valuable contribution regarding the additional evidence to the organization within this field.
\end{abstract}

\section{Keywords}

JEL Classification organizational politics, proactive behavior, self-efficacy, employees, perception, local government, moderation

H11, M54, O15

\section{INTRODUCTION}

Good governance is when the government is clean, authoritative (Streck, 2007), and free of political impression (Landells \& Albrecht, 2017). However, organizational politics can affect all aspects and is difficult to eliminate directly (Amyulianthy, Khair, \& Lysandra, 2016). Since some employees use a political approach in achieving power and career in the organization (Hsiung, C. W. Lin, \& C. S. Lin, 2012; Judge \& Bretz Jr, 1994). Almost all government employees in Indonesia can talk about political events because they are involved directly or indirectly in the implementation of organizational politics in their environment. This organizational political event has a psychological impact on employees who work for the benefit of the organization (Landells \& Albrecht, 2013). The employees consider that organizational politics is a quick way to gain power and position. As a result, some people claim that politics has a negative impact on others and the organization (Vigoda, 2000), while some other employees who got promotions in political ways consider politics as a useful tool in the development of themselves and their organizations (Kacmar \& Carlson, 1997). 
The negative impact of organizational politics on government institutions triggers criminal acts of corruption by government employees to gain power by using methods they consider easy and fast. Based on the data from the Indonesian Corruption Eradication Commission, criminal acts of corruption that occurred at government institutions included bribery, personal enrichment, embezzlement in office, and fraud in procurement, as many as 887 cases, which occurred from 2004 to 2018 . The government institutions, which were stated as having the most criminal acts of corruption, were ministries (321 cases), district or city governments (295 cases), provincial governments (128 cases), House of Representatives or DPR and Regional House of Representatives or DPRD (67 cases), state-owned enterprises and provincially/municipally-owned corporations (56 cases). Meanwhile, the institution with the least case was the commission (20 cases) (Roosyana, 2019). Criminal acts of corruption in government institutions are part of the organizational politics in achieving personal and group benefits (Landells \& Albrecht, 2017; Zivnuska, Kacmar, Witt, Carlson, \& Bratton, 2004).

In the context of organizational political study, most of the studies were conducted on American culture that is individualistic (Miller, Rutherford, \& Kolodinsky, 2008). In Chinese culture, which is collectivist, individuals believe that harmony is virtue and brotherhood (Olson, Bao, \& Parayitam, 2014). Meanwhile, an organizational political study in government institutions in Indonesia tended to be small in number. The fundamental difference of those studies lies in Indonesian culture, which has the ideology of Divinity, in which individuals believe that everything possessed by a person, namely good skills, experience, and self-confidence, is derived from God and shall return to God. This trust becomes an essential component in individual behavior in government institutions in Indonesia. Therefore, it is crucial to examine in-depth organizational politics in government organizations because the impact can affect the behavior of individuals, groups, and organizations. Besides, this study tries to explain how the organizational context (organizational politics) and individuals context (self-efficacy) interact to influence the proactive behavior of employees in government institutions.

\section{LITERATURE REVIEW AND HYPOTHESES DEVELOPMENT}

\subsection{Effect of organizational politics on proactive behavior}

As work becomes more dynamic and decentralized, proactive behavior and initiative behavior become important determinants of organizational success (Huang, 2017). Proactive behavior is the use of initiative of someone in improving the current situation or creating a new one. Proactive behavior challenges the status quo condition that passively adapts to the current state (Nurjaman, Marta, Eliyana, Dewi Kurniasari, \& Dedeh Kurniasari, 2019). The employee's proactive behavior can be influenced by environmental factors (contextual factors) or individual factors (individual differences). The environment can increase proactive behavior of employees. On the contrary, it can also reduce the proactive behavior of employees. One thing that can reduce the proactive behavior is organizational politics, which is considered a negative factor in employee commitment and satisfaction (Bozeman, Hochwarier, Perrewe, \& Brymer, 2001).

In employees' opinion, organizational politics has a negative image because it is only concerned with personal and group interests (Vigoda, 2000). Many studies have evidenced the potential threat of organizational politics to the efficiency and effectiveness of organizations. The study by Rosen, Ferris, Brown, Chen, and Yan (2014) showed that organizational politics had a negative effect on the proactive behavior of employees at Internet companies in Guangzhou, China. The results of the study are supported by Lau, Tong, Lien, Hsu, and Chong (2017) who evidenced that the political reward system had a negative effect on proactive customer service performance in six shopping malls in Kuala Lumpur, Malaysia. The study explained that organizational politics had a negative impact on 
the proactive behavior of employees because politics participates in organizational processes. In other words, if organizational politics is involved in the organizational decision-making process, then political compromise would be made. As a result, organizational progress was hampered since the organization was more concerned with compromise in the interests of the group than in the interests of the organization (Kacmar, Bozeman, Carlson, \& Anthony, 1999; Kacmar \& Carlson, 1997; Zivnuska, Kacmar, Witt, Carlson, \& Bratton, 2004). Organizational politics consists of general political behavior, way forward, salary, and promotion policies (Kacmar \& Carlson, 1997). Organizational politics that emphasizes the benefits of oneself and his group both now and in the future can reduce the proactive behavior of employees. Thus, organizational politics has a negative impact on the stability of employee behavior and can reduce employee performance.

H1: Organizational politics has a negative effect on proactive behavior.

\subsection{Effect of organizational politics on proactive behavior is moderated by self-efficacy}

The social cognitive theory proposes a triadic cause-and-effect relationship between person, his/her behavior, and the organization, and explains that people are both products and producers of their own environment (Borgogni, Russo, \& Petitta, 2010). Besides, behavioral plasticity theory states that external factors can trigger a person's behavior. In other words, someone who has self-efficacy can interact with the environment in which he exists (Liu, Cho, \& Putra, 2017; Pierce, Gardner, Dunham, \& Cummings, 1993). Self-efficacy is a person's belief in his ability to manage the actions needed to get better results. People who have self-efficacy tend to be more confident; they also have a more positive attitude towards their life and works and have lower levels of stress and anxiety. As a result, they tend not to be disturbed by negative environmental and psychological situations (Liu, Cho, \& Putra, 2017). Thus, self-efficacy belief has an effect on the members' perceptions in a social context (Borgogni et al., 2010).
A study by Raub and Liao (2012) showed that self-efficacy had a positive effect on employee proactive customer service performance in European hotels. Besides, the study was supported by Huang (2017) who stated that self-efficacy had a positive effect on proactive behavior. Furthermore, self-efficacy could mediate the impact of psychological empowerment and proactive behavior among Master of Business Administration students of the business faculties of four universities in South China. Meanwhile, a study by Chairina, Sularso, Tobing, and Irawan (2019) showed that self-efficacy has a significant negative effect on burnout among private hospital nurses in East Java. Besides, Bozeman et al. (2001) stated that self-efficacy was one of the reinforcing factors for the negative relationship between organizational politics with organizational commitment and job satisfaction. This was related to the attitude so that employees had negative assumptions on their environment. In particular, individuals with high self-efficacy view organizational politics as an obstacle. Conversely, individuals with low self-efficacy see organizational politics more as an opportunity.

Organizational politics is a condition where the organization is considered to run political practices in the system that has been running. The consequences of organizational politics on the proactive behavior of employees are negative. However, the negative influence of organizational politics can be weakened by self-efficacy based on the assumptions conveyed by Pierce et al. (1993) who state that individuals with high abilities can adapt quickly even in a conflict-filled environment. This means that someone who has high self-efficacy can reduce the effects of organizational politics on the proactive behavior of employees.

H2: Moderation of self-efficacy will weaken the negative relationship between organizational politics and proactive behavior.

The conceptual model that shows the moderating effect of self-efficacy on the relationship between organizational politics and proactive behavior is presented in Figure 1. 


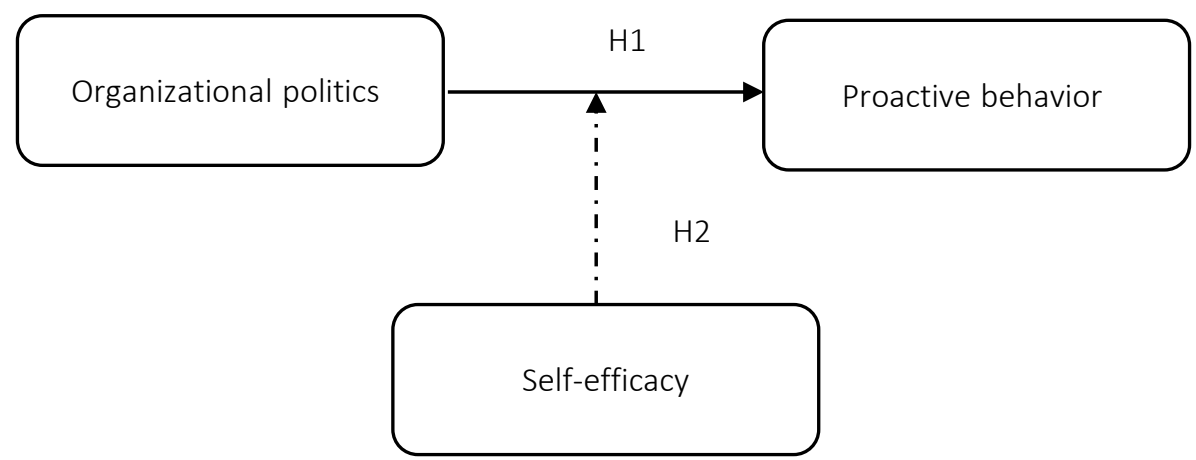

Figure 1. Conceptual model

\section{METHODOLOGY}

\subsection{Sample and procedures}

An explanatory method with a quantitative approach was used in this study. Furthermore, a survey is conducted among 310 employees in 4 regional government offices, namely Bandung City, Cimahi City, Bandung District, and West Bandung Regency, Indonesia. Probability sampling technique with systematic random sampling was used to determine the samples that followed certain systematic rules in the population. In the classification of the respondents' demographics by gender, the majority were male (58\%), and $42 \%$ of respondents were female. Based on the marital status, the majority of respondents were married (75\%), and $25 \%$ of respondents were not married. Based on education, the majority of respondents had a bachelor's degree (65\%), 25\% of respondents had a master's degree, and $15 \%$ of respondents had senior high school education.

The statistical analysis method in this study used Moderated Regression Analysis (MRA), this statistical analysis tries to analyze and explain how the moderating variable position in the study, whether the moderating variable is a pure moderating variable, quasi moderating variable, or not a moderating variable. Besides, the test is intended to find out how the role of the moderating variable between the independent variable and the dependent variable, whether it can strengthen or weaken the relationship (Helm \& Mark, 2012; Sharma, Durand, \& Gur-Arie, 1981). Meanwhile, to facilitate the statistical analysis, the authors used STATA 13 software to test the direct effect of moderating variable.

\subsection{Measurement}

The measurement standard for self-efficacy was seven indicators measurement developed by Borgogni et al. (2010). As for the measurement of organizational politics, there were 15 indicators adopted by Kacmar and Carlson (1997). In the measurement of proactive behavior, the authors used seven indicators adopted from Frese, Fay, Hilburger, Leng, and Tag (1997). All the answer scales were explained in this section with a Likert scale ranging from 1 (strongly disagree) to 5 (strongly agree).

\section{RESULTS}

The analysis of study instruments consisted of validity and reliability tests, which are intended to determine the level of accuracy and consistency of the measuring instruments used. Validity test used corrected item-total correlation with a validity level of more than 0.30 , while reliability test used Cronbach's alpha with a reliable level of more than 0.60 (Escobar, Trujillo-Martín, Rueda et al., 2015). The results of the validity and reliability tests are shown in Table 1.

Based on Table 1, each item statement of employee perceptions about organizational politics, self-efficacy, and proactive behavior was declared valid because it had a value of more than 0.30 . Furthermore, the reliability test showed that all variables in this study were reliable since each variable had a reliability value of more than 0.60 .

Moderated Regression Analysis (MRA) is the statistical analysis method used in this study. 
Table 1. Results of validity and reliability tests

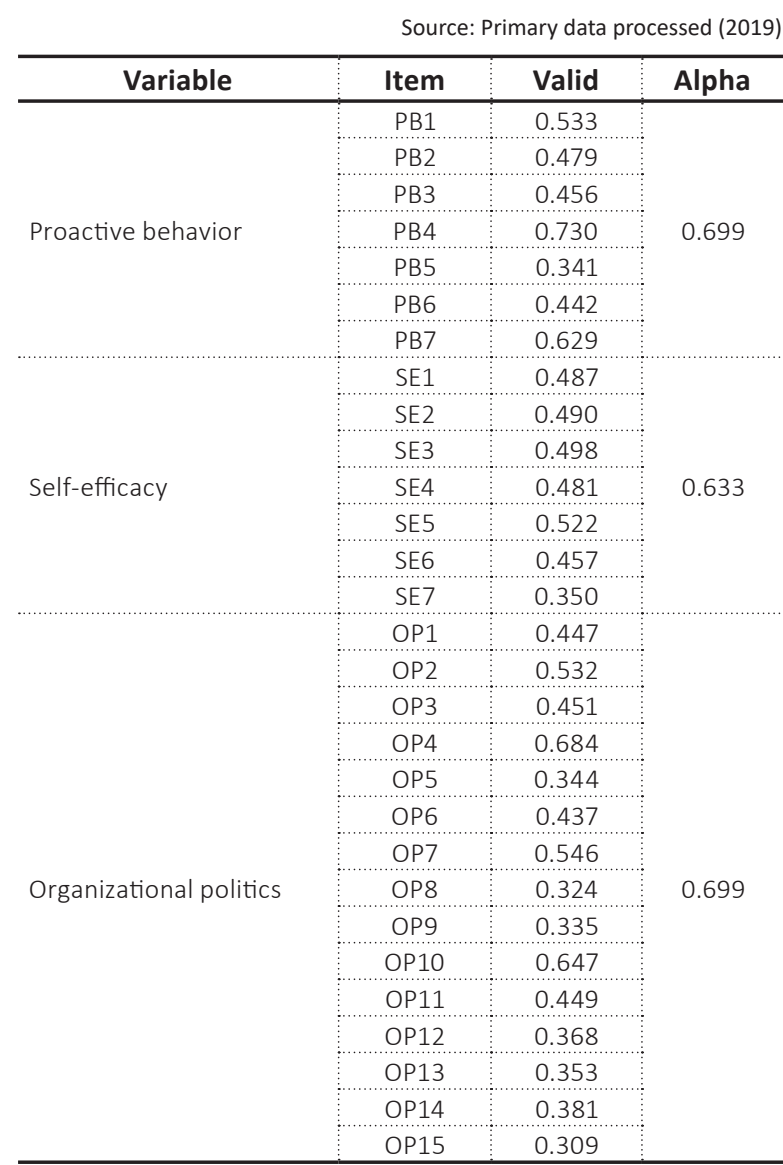

According to Sharma, Durand, and Gur-Arie (1981), moderation test is carried out by the following stages:

1) examining the direct relationship between the independent variable (organizational politics) and the dependent variable (proactive behavior);

2) examining the direct relationship between the independent variable (organizational politics), the moderating variable (self-efficacy), and the dependent variable (proactive behavior);
3) testing the independent variable (organizational politics), moderating variable (self-efficacy), the product of the independent and moderating variables (organizational politics ${ }^{*}$ self-efficacy), and the dependent variable (proactive behavior).

The test steps can be determined with the Moderated Regression Analysis (MRA) test equations as follows:

$$
\begin{gathered}
Y=\alpha+\beta_{1} X_{1}+\varepsilon, \\
Y=\alpha+\beta_{1} X_{1}+\beta_{2} X_{2}+\varepsilon, \\
Y=\alpha+\beta_{1} X_{1}+\beta_{2} X_{2}+\beta_{3} X_{1} X_{2}+\varepsilon .
\end{gathered}
$$

The above equation was then used as the basis for an analysis of how self-efficacy interacted in the relationship between organizational political and proactive behavior of government employees. The results of the statistical analysis by MRA test can be presented as follows:

Model 1 in Table 2 showed that organizational politics had a negative effect on the proactive behavior of government employees, with a coefficient of -0.183 and a $p$-value of 0.000 . The $p$-value obtained was less than 0.05 , so that it can be stated that the value of $\beta 1$ was significantly negative. This indicated that organizational politics could weaken the effect of proactive behavior of government employees. Model 2 showed that self-efficacy had a positive impact on the practice behavior of government employees, with a coefficient value of 0.313 and a $p$-value of 0.000 or less than 0.05 . This value indicated that $\beta 2$ was significantly positive. Model 3 showed the interaction of organizational politics and self-efficacy, which showed a coefficient value of -0.323 and $p$-value of 0.068 , so that it can be stated that $\beta 3$ value was not significant. Based on the Moderated

\begin{tabular}{|c|c|c|c|c|c|c|}
\hline \multirow{2}{*}{ Constant, variables } & \multicolumn{2}{|c|}{ Model 1} & \multicolumn{2}{|c|}{ Model 2} & \multicolumn{2}{|c|}{ Model 3} \\
\hline & Coef. & $\mathbf{p}$ & Coef. & p & Coef. & $\mathbf{p}$ \\
\hline Constant $(a)$ & 4.194 & 0.000 & 3.550 & 0.000 & -0.938 & 0.705 \\
\hline Organizational politics $\left(X_{1}\right)$ & -0.183 & 0.024 & -0.349 & 0.000 & 0.924 & 0.189 \\
\hline Self-efficacy $\left(X_{2}\right)$ & - & - & 0.313 & 0.000 & 1.454 & 0.021 \\
\hline Organizational politics*self-efficacy & - & - & - & - & -0.323 & 0.068 \\
\hline $\mathrm{F}$ & 5.13 & 0.024 & 15.70 & 0.000 & 11.66 & 0.000 \\
\hline$R$-squared & \multicolumn{2}{|c|}{0.016} & \multicolumn{2}{|c|}{0.092} & \multicolumn{2}{|c|}{0.102} \\
\hline
\end{tabular}

Table 2. Results of Moderated Regression Analysis

Source: Results of the analysis by STATA 2019. 
Regression Analysis (MRA) test, if $\beta 1, \beta 2$, and $\beta 3$ were insignificant, then self-efficacy was a pure moderator in the relationship between organizational politics and proactive behavior (Sharma, Durand, \& Gur-Arie, 1981; Zedeck, 1971).

\section{DISCUSSION}

The negative impact of organizational politics on the proactive behavior of government employees needs to be studied more deeply to find out how organizational politics can weaken the proactive behavior of government employees. Individuals who have high proactive behavior tend to have dedication, initiative, and a strong desire to develop their organization (Parker, Bindl, \& Strauss, 2010). Besides, this individual develops creative ideas to do every work (Parker, Williams, \& Turner, 2006). However, proactive individuals can also change and be influenced by environmental and personality factors, so that they reduce the behavior of their initiatives for organizational progress. One of them is organizational politics, which is the cause of the employee's proactive behavior to decrease (Lau et al., 2017; Rosen et al., 2014). Organizational politics is associated with employees' negative perceptions of the assessment system, salaries, promotions, and rewards conducted by the organization to himself and his partners. This negative perception underlies whether the organization is fair in distributing the existing resources to its employees without having to consider closeness. On the other hand, organizational politics deals with individual behavior that can benefit his interests and neglects the interests of the organization and its colleagues strategically (Vigoda, 2000).

This study has confirmed that organizational politics in government institutions could cause a decrease in the proactive behavior of employees in carrying out the work given to them. Organizational politics could weaken the proactive behavior of government employees because government institutions are not privately owned, so they must be free from personal and group interests. Thus, if political interests dominate in government organizations, the proactive behavior of employees will decrease and affect organizational performance. Individuals who do politics in their government organizations tend to take advantage of themselves and their groups. As a result, a negative perception of employees will be formed in an organization. These employees' perceptions must be avoided if government organizations have the aim to develop and grow employee performance for the benefit of the organization. In other words, the existence of organizational politics is an individual interpretation of the organizational climate (Lee, Yang, Wan, \& Chen, 2010).

Furthermore, employee proactive behavior can also be influenced by personality factors that employees have. Individuals with strong personalities will give priority to being proactive in the workplace, have a higher readiness to assume responsibility and be persistent in doing work (Ghitulescu, 2012). Self-efficacy is a personality factor that can affect employees in behavior (Nugroho, Hidayat, \& Kusuma, 2017) and self-efficacy is created with experience, knowledge, and confidence (Chairina et al., 2019). This study explained that self-efficacy was a moderating variable between organizational politics and proactive behavior. The effect of self-efficacy on organizational political relations and proactive behavior was a factor that can weaken the negative influence of organizational politics among district and city government employees in Bandung. According to Borgogni et al. (2010), self-efficacy can influence behavior directly and can also influence other factors such as affective disposition, perception of obstacles, and opportunities inherent in the social environment. On the other hand, organizational politics is an opportunity for employees to achieve the expectations of themselves and their groups without needing optimal abilities and skills. Unlike someone who has self-efficacy in their work, they as a whole have a feeling of trust and competence that tend to supervise and master them to carry out tasks maximally without being able to be influenced by their environment (Liu, Cho, \& Putra, 2017). Therefore, high self-efficacy can reduce the negative impact of perceived organizational politics of the employees in their organizations. Therefore, self-efficacy must be improved so that organizations avoid organizational politics that adversely affect the commitment, satisfaction, and performance of employees.

Behavioral plasticity theory states that a person's behavior refers to the extent to which external factors influence him. That is, individuals with low self-efficacy are more vulnerable/soft to external influences than individuals with high self-efficacy. In other words, individuals with low self-efficacy are more 
easily influenced by conditions in the work environment and organizational characteristics in their workplace (Liu, Cho, \& Putra, 2017; Pierce et al., 1993). Self-efficacy is a factor of individuals who are trained based on their experience, abilities, and confidence so that they can provide strong confidence to do every job given to them regardless of the environmental conditions they face. The political situ- ation cannot influence someone with high self-efficacy in the organization. On the contrary, someone with high self-efficacy can weaken the negative effect of organizational politics on individual behavior. Proactive behavior is a consequence of positive interactions of self-efficacy and organizational politics, hence proactive behavior will increase along with the increase in employee self-efficacy.

\section{CONCLUSION}

Based on the results and discussion of this research, organizational politics statistically had a negative effect on the proactive behavior of local government employees, Indonesia. In other words, organizational politics can weaken the proactive behavior of government employees. The organizational politics exists in a country that must be wary of since organizational politics will have an adverse effect on the organization in general, and especially the proactive behavior of employees. Organizational politics was considered as an opportunity to achieve goals for those who had not been qualified enough to occupy certain positions in the organization. As for those who were qualified, organizational politics was considered as an obstacle in achieving the individual goals. Furthermore, the moderation effect of self-efficacy found can weaken the negative relationship between organizational politics and proactive behavior of government employees. Employees who had high self-efficacy made the negative effects of organizational politics on the proactive behavior of government employees weak. The negative relationship between organizational politics and proactive behavior became weak because employees who had self-efficacy provided themselves with sufficient knowledge about competence, deep experience related to the position they occupied. The experience and competence of employees became a force in influencing proactive behavior in the face of organizational politics.

\section{LIMITATIONS}

This study certainly has limitations in its implementation, so it is necessary to conduct further research related to organizational politics. First, the study sampling was only focused on local governments. In a further study, the sampling should consider other government sectors such as education, service, and provincial government, etc. Second, this study only used the moderating variable of self-efficacy, whereas the big five personality factors can also have a moderating effect on the relationship between organizational politics and proactive behavior. In other words, many variables have not been examined in this study. Third, this study only used the samples of government employees. The use of private employees in further research is recommended to increase scientific knowledge.

\section{REFERENCES}

1. Amyulianthy, R., Khair,

J., \& Lysandra, S. (2016).

Characteristics and Political

Connection To Local Government

Performance. Jurnal ASET

(Akuntansi Riset), 8(2), 1-14.

https://doi.org/10.17509/jaset. v8i2.12527

2. Borgogni, L., Russo, S. Dello, \& Petitta, L. (2010). Predicting Job
Satisfaction and Job Performance in a Privatized Organization. International Public Management Journal, 13(3), 275-296. https:// doi.org/10.1080/10967494.2010. 504114

3. Bozeman, D. P., Hochwarier, W. A., Perrewe, P. L., \& Brymer, R. A. (2001). Organizational politics, perceived control, and work outcomes: Boundary conditions on the effects of politics. Journal of Applied Social Psychology, 31(3), 486-503. https://doi. org/10.1111/j.1559-1816.2001. tb02052.x

4. Chairina, R. R. L., Sularso, R. A., Tobing, D. S. K., \& Irawan, B. (2019). Determinants of nurse performance in accredited 
Indonesian private hospitals. Problems and Perspectives in Management, 17(1), 163-175. https://doi.org/10.21511/ ppm.17(1).2019.15

5. Escobar, A., Trujillo-Martín, M. del M., Rueda, A., Pérez-Ruiz, E., Avis, N. E., \& Bilbao, A. (2015). Cross-cultural adaptation, reliability and validity of the Spanish version of the Quality of Life in Adult Cancer Survivors (QLACS) questionnaire: Application in a sample of shortterm survivors. Health and Quality of Life Outcomes, 13(1), 1-14. https://doi.org/10.1186/s12955015-0378-2

6. Frese, M., Fay, D., Hilburger, T., Leng, K., \& Tag, A. (1997). The concept of personal initiative: Operationalization, reliability and validity in two German samples. Journal of Occupational and Organizational Psychology, 70(2), 139-161. https://doi. org/10.1111/j.2044-8325.1997. tb00639.x

7. Ghitulescu, B. E. (2012). Making Change Happen: The Impact of Work Context on Adaptive and Proactive Behaviors. Journal of Applied Behavioral Science, 49(2), 206-245. https://doi. org/10.1177/0021886312469254

8. Helm, R., \& Mark, A. (2012). Analysis and evaluation of moderator effects in regression models: State of art, alternatives and empirical example. Review of Managerial Science, 6(4), 307-332. https://doi.org/10.1007/s11846010-0057-y

9. Hsiung, H. H., Lin, C. W., \& Lin, C. S. (2012). Nourishing or suppressing? The contradictory influences of perception of organizational politics on organizational citizenship behaviour. Journal of Occupational and Organizational Psychology, 85(2), 258-276. https://doi.org/10.1111/j.20448325.2011.02030.x

10. Huang, J. (2017). The relationship between employee psychological empowerment and proactive behavior: Self-efficacy as mediator. Social Behavior and Personality,
45(7), 1157-1165. https://doi. org/10.2224/sbp.6609

11. Judge, T. A., \& Bretz Jr, R. D. (1994). Political influence processes and career success. Journal of Management, 20(1), 43-65.

12. Kacmar, K. M., \& Carlson, D S. (1997). Further validation of the perceptions of politics scale (pops): A multiple sample investigation. Journal of Management, 23(5), 627-658. https://doi. org/10.1177/014920639702300502

13. Kacmar, K. M., Bozeman, D. P., Carlson, D. S., \& Anthony, W. P. (1999). An Examination of the Perceptions of Organizational Politics Model: Replication and Extension. Human Relations, 52(3), 383-416. https://doi. org/10.1177/000841745502200404

14. Landells, E. M., \& Albrecht, S. L. (2017). Positive politics, negative politics, and engagement: Psychological safety, meaningfulness, and availability as "black box" explanatory mechanisms. Research in Occupational Stress and Well Being, 15, 33-49. https://doi.org/10.1108/ S1479-355520170000015004

15. Landells, E., \& Albrecht, S. L. (2013). Organizational political climate: Shared perceptions about the building and use of power bases. Human Resource Management Review, 23(4), 357365. https://doi.org/10.1016/j. hrmr.2012.06.014

16. Lau, P. Y. Y., Tong, J. L. Y. T., Lien, B. Y. H., Hsu, Y. C., \& Chong, C. L. (2017). Ethical work climate, employee commitment and proactive customer service performance: Test of the mediating effects of organizational politics. Journal of Retailing and Consumer Services, 35, 20-26. https://doi.org/10.1016/j.jretconser.2016.11.004

17. Lee, Y. H., Yang, L. S., Wan, K. M., \& Chen, G. H. (2010). Interactive effects of personality and friendship networks on contextual performance. Social Behavior and Personality, 38(2), 197-208. https:// doi.org/10.2224/sbp.2010.38.2.197
18. Liu, J., Cho, S., \& Putra, E. D. (2017). The moderating effect of self-efficacy and gender on work engagement for restaurant employees in the United States. International Journal of Contemporary Hospitality Management, 29(1), 624642. https://doi.org/10.1108/ IJCHM-10-2015-0539

19. Miller, B. K., Rutherford, M. A., \& Kolodinsky, R. W. (2008). Perceptions of organizational politics: A meta-analysis of outcomes. Journal of Business and Psychology, 22(3), 209-222. https:// doi.org/10.1007/s10869-0089061-5

20. Nugroho, A. P., Hidayat, A., \& Kusuma, H. (2017). The influence of religiosity and self-efficacy on the saving behavior of the slamic banks. Banks and Bank Systems, 12(3), 35-47. https://doi. org/10.21511/bbs.12(3).2017.03

21. Nurjaman, K., Marta, M. S., Eliyana, A., Kurniasari, Dewi, \& Kurniasari, Dedeh (2019). Proactive work behavior and innovative work behavior: Moderating effect of job characteristics. Humanities and Social Sciences Reviews, 7(6), 373-379. https://doi.org/10.18510/ hssr.2019.7663

22. Olson, B., Bao, Y., \& Parayitam, S. (2014). Political behavior, trustworthiness, job satisfaction, and commitment: An empirical study. Chinese Management Studies, 8(3), 354-374. https://doi. org/10.1108/CMS-09-2012-0129

23. Parker, S. K., Bindl, U. K., \& Strauss, K. (2010). Making things happen: A model of proactive motivation. Journal of Management, 36(4), 827-856. https://doi. org/10.1177/0149206310363732

24. Parker, S. K., Williams, H. M., \& Turner, N. (2006). Modeling the antecedents of proactive behavior at work. Journal of Applied Psychology, 91(3), 636-652. https://doi.org/10.1037/00219010.91.3.636

25. Pierce, J. L., Gardner, D. G., Dunham, R. B., \& Cummings, L. L. (1993). Moderation By 
Organization-Based Self-Esteem of Role Condition-Employee Response Relationships. Academy of Management Journal, 36(2), 271-288. https://doi. org/10.5465/256523

26. Raub, S., \& Liao, H. (2012). Doing the right thing without being told: Joint effects of initiative climate and general self-efficacy on employee proactive customer service performance. Journal of Applied Psychology, 97(3), 651-667. https://doi.org/10.1037/a0026736

27. Roosyana, R. (2019, March). Penindakan Jual Beli Jabatan seperti Gunung Es. Beritagar.Id. Retrieved from https://beritagar. id/artikel/berita/penindakan-jualbeli-jabatan-seperti-gunung-es

28. Rosen, C. C., Ferris, D. L., Brown, D. J., Chen, Y., \& Yan, M. (2014).
Perceptions of organizational politics: A need satisfaction paradigm. Organization Science, 25(4), 1026-1055. https://doi. org/10.1287/orsc.2013.0857

29. Sharma, S., Durand, R. M., \& Gur-Arie, O. (1981). Identification and Analysis of Moderator Variables. Journal of Marketing Research, 18(3), 291-300. https://doi. org/10.2307/3150970

30. Streck, C. (2007). The governance of the Clean Development Mechanism: the case for strength and stability. Environmental Liability, 2, 91-100. Retrieved from http://www.gppi.net/ fileadmin/gppi/EL-15-2-Streckfinal_04_06_07.pdf

31. Vigoda, E. (2000). Organizational Politics, Job Attitudes, and
Work Outcomes: Exploration and Implications for the Public Sector. Journal of Vocational Behavior, 57(3), 326-347. https:// doi.org/10.1006/jvbe.1999.1742

32. Zedeck, S. (1971). Problems with the use of "moderator" variables. Psychological Bulletin, 76(4), 295-310. https://doi.org/10.1037/ h0031543

33. Zivnuska, S., Kacmar, K. M., Witt, L. A., Carlson, D. S., \& Bratton, V. K. (2004). Interactive effects of impression management and organizational politics on job performance An Expectancy Theory Perspective on Organizational. Journal of Organizational Behavior, 25, 627-640. https://doi.org/10.1002/ job. 262 